Portland State University

PDXScholar

$11-1-2019$

\title{
Plea Decision-making: the Influence of Attorney Expertise, Trustworthiness, and Recommendation
}

\author{
Kelsey S. Henderson \\ Portland State University, kelsey.henderson@pdx.edu \\ Reveka Shteynberg \\ California State University - San Bernardino
}

Follow this and additional works at: https://pdxscholar.library.pdx.edu/ccj_fac

Part of the Experimental Analysis of Behavior Commons, Industrial and Organizational Psychology Commons, and the Social Psychology Commons

Let us know how access to this document benefits you.

\section{Citation Details}

PREPRINT Henderson, K. S., \& Shteynberg, R. V. (2019). Plea decision-making: the influence of attorney expertise, trustworthiness, and recommendation. Psychology, Crime \& Law, 1-25.

This Pre-Print is brought to you for free and open access. It has been accepted for inclusion in Criminology and Criminal Justice Faculty Publications and Presentations by an authorized administrator of PDXScholar. Please contact us if we can make this document more accessible: pdxscholar@pdx.edu. 
PRE-PRINT Henderson, K. S. \& Shteynberg, R. V. (2020). Plea Decision-making: The Influence of Attorney Expertise, Trustworthiness, and Recommendation. Psychology, Crime \& Law, 26(6), 527-551. https://doi.org/10.1080/1068316X.2019.1696801

Plea Decision-Making:

The Influence of Attorney Expertise, Trustworthiness, and Recommendation

\author{
Kelsey S. Henderson \\ Portland State University \\ Reveka V. Shteynberg \\ California State University San Bernardino
}

Kelsey S. Henderson, Department of Criminology \& Criminal Justice, Portland State University; Reveka V. Shteynberg, Department of Criminal Justice, California State University San Bernardino

Correspondence concerning this article should be address to Kelsey S. Henderson, Department of Criminology \& Criminal Justice, P.O. Box 751, Portland, OR, 97201. E-mail:

Kelsey.henderson@pdx.edu

Author Note: This study was supported by a Hatfield Public Service grant (Portland State University). Selected findings were presented at the 2018 American Society of Criminology annual conference (Atlanta, GA). 


\begin{abstract}
(<200 words)
Attorney recommendations influence defendant plea decisions (Henderson \& Levett, 2018; Viljoen, Klaver, \& Roesch, 2005). The degree of influence likely rests on the perceived trustworthiness and level of expertise of the attorney (factors of source credibility). We explored attorney source credibility factors and how these characteristics influence defendants' plea decision-making. MTurk participants read a hypothetical plea scenario and were asked to imagine themselves as the defendant in a DWI/DUI case making a plea decision; in the scenario, we manipulated the defense attorney's level of trustworthiness, expertise, and plea recommendation. There was a significant interaction between attorney recommendation and trustworthiness on defendants' plea decisions; participants who were advised to accept the guilty plea were more likely to plead guilty when the attorney was high in trustworthiness compared to low in trustworthiness. Attorney trustworthiness did not affect plea decisions for defendants advised to reject the guilty plea. Importantly, attorney trustworthiness affected defendants' decision to follow the attorney's recommendation and ultimate plea decision (regardless of expertise), and attorney expertise affected defendants' confidence in their decision (regardless of trustworthiness). Results suggest individual-level characteristics of defense attorneys affect the influence of the attorney and their recommendation, and ultimately defendants' plea decisionmaking.
\end{abstract}

Keywords: plea bargaining, defense attorneys, guilty pleas, attorney influence, effective assistance of counsel

Word Count: 9,263 
Plea Decision-Making: The Influence of Attorney Expertise, Trustworthiness, and

\section{Recommendation}

In the American criminal justice system, guilty pleas constitute the majority of criminal convictions (roughly 95\%; Cohen \& Reaves, 2006). Acknowledging this reality, the U.S. Supreme Court recently focused specific attention on the relationship between defendant and counsel in plea decision-making (Lafler v. Cooper, 2012; Missouri v. Frye, 2012). Research has explored the role of attorneys and their recommendations on plea decision-making (more below), but that research does not elucidate how characteristics of the attorney influence defendants' willingness to follow their attorneys' plea recommendation. A relatively large body of empirical literature is available focusing on decision-making by juries; this literature finds that individual characteristics of attorneys, particularly perceptions of credibility, influence juror decisionmaking (Devine, 2001; Hahn \& Clayton, 1996). It is possible that these characteristics -attorney expertise and trustworthiness - have a similar effect on defendants' plea decision-making, although causal research has not examined this to date.

The goal of this project was to explore the relationship between defendant and attorney in plea decision-making; specifically, how defendants evaluate their attorney, and if individuallevel characteristics influence willingness to follow their attorneys' recommendation. We first conducted a pilot study exploring indicators of attorney expertise and trustworthiness. The findings were used to create a hypothetical scenario (see Appendix) in which we manipulated these factors (i.e., low vs. high expertise and trustworthiness) to explore how attorney characteristics and recommendation influence defendant plea decision-making.

\section{Plea Bargaining and Defendant Decision-making}

For defendants, the decision to waive one's right to trial and plead guilty is likely one of 
the most important legal decisions they will make, carrying potentially life-long consequences. On any given day, in the criminal justice system, thousands of criminal defendants are facing this decision. In 2004, over 1 million adults were convicted of a felony in U.S. State courts; $95 \%$ of those defendants pleaded guilty (Durose \& Langan, 2006). Self-report data suggests that defendants are motivated to accept a guilty plea by the desire to expedite the process (i.e., get the process over with), perception of the strength of evidence against them, and instrumental factors, such as accepting the guilty plea to lessen the possible punishment and avoid more severe punishment at trial (other motivations listed: Bordens \& Bassett, 1985; Malloy, Shulman, and Cauffman, 2014; Redlich \& Shteynberg, 2016).

The decision of whether to accept or reject a guilty plea offer is a complex process for the defendant, which involves cognitive biases, heuristics, and social influence (Redlich, Bibas, Edkins, \& Madon, 2017). One likely source of social influence on the defendant's decision is his defense attorney (Henderson \& Levett, 2018; Redlich et al., 2017). Attorneys, because of their position, education, and training often act as the defendant's main source of legal information. In addition, defense attorneys may be able to facilitate greater client participation in the process and better decision-making (Fountain \& Woolard, 2018). As stated in Powell v. Alabama (1932), the defendant "requires the guiding hand of counsel in each step of the proceedings against him" (p. 69). In making the important decision of whether and when to waive one's rights and accept a guilty plea, defendants look to their attorneys, and research suggests defense attorneys play an influential role in these decisions (Viljoen, Klaver, \& Roesch, 2005).

\section{Legal Role of Attorneys}

Defense counsel has been described as a 'primary safeguard of fairness in plea bargaining' (Alschuler, 1975) as well as the 'equalizer' (Wright, 1966) and 'adequate protective 
device necessary' (Miranda v. Arizona, 1966) in both the plea-bargaining process specifically and the criminal justice system generally. The scope of the sixth amendment right to an attorney, throughout criminal proceedings, was more fully articulated in Brewer v. Williams (1977): the right to counsel "[means] at least that a person is entitled to the help of a lawyer at or after the time that judicial proceedings have been initiated against him, whether by formal charge, preliminary hearing, indictment, information, or arraignment" (p. 398). Shortly before this, in 1970, three U.S. Supreme Court cases shifted guilty-plea litigation from the issue of plea voluntariness to the right to effective assistance of counsel (Brady v. United States, 1970; McMann v Richardson, 1970; Parker v. North Carolina, 1970).

Forty years later, Lafler (2012) and Frye (2012) reframed the issue from the general right to effective counsel (i.e., right to representation by a competent, effective attorney; see Strickland v. Washington, 1984) to a defendant's right to receive legal relief from guilty pleas resulting from ineffective assistance of counsel (i.e., ability to successfully appeal a guilty plea conviction on the basis of ineffective legal representation). Most recently, in a case where the defendant's attorney disregarded his client's wish to assert his innocence at trial (rather than plead guilty) and then admitted the defendant's guilt to the jury, the U.S. Supreme Court reaffirmed that the decision of how to plead lies with the defendant, not their attorney (in addition to the decision to waive other rights; McCoy v. Louisiana, 2018). A central theme of these cases has been the reinterpretation of the right to counsel, shifting the focus of defense counsel's role from mere presence to the quality and substance of attorney-client interactions.

\section{Influence of Attorneys in Plea Decisions}

Defense attorneys play an important role in defendants' decision-making throughout the case, beginning with how defendants come to understand the process, including the information 
with which they are able to navigate the complexities of the justice system. For defendants accepting a guilty plea, they must demonstrate that they are making a knowing, intelligent, and voluntary decision to waive their right to trial (Boykin v. Alabama, 1969). The defense attorney can assist the defendant in this area, and typically defendants make a plea decision with their attorney's involvement and after consideration of their attorney's recommendation. Attorneys play a crucial role in defendants' plea decisions; in fact, a defendant's own defense attorney is likely the first to recommend accepting a guilty plea, rather than going to trial (Blumberg, 1967).

Generally, researchers have found that attorneys influence plea decisions, particularly for more susceptible populations (see Malloy et al., 2014; Redlich, Summers, \& Hoover, 2010; Viljoen et al., 2005). In a study examining juveniles' legal decisions, over $50 \%$ of defendants who were given advice by their attorney, reported that their attorney advised them to plead guilty, and that advice influenced their willingness to accept a guilty plea (Viljoen et al., 2005). Experimental research, using a simulated plea-bargaining situation, has also found the influence of an advocate's recommendation affects plea decisions (Henderson \& Levett, 2018). In this study, participants were accused of academic dishonesty, half were guilty of the crime and half innocent, and presented with the option of admitting guilt and accepting the lab punishment or taking their case before the student conduct committee. They then heard advice from a university advocate (analogous to an attorney) about how to resolve their case. Across both innocent and guilty conditions, the attorney was rated as more helpful when they recommended going to trial compared to when they recommended accepting the guilty plea or gave educational information. Overall, research suggests that attorneys influence defendants' plea decisions (Viljoen et al., 2005), and the content of their advice influences decisions and ratings of the attorney (Henderson \& Levett, 2018). To date, less research has explored if characteristics of the source of that 
information (e.g., the attorney's level of trustworthiness) affect willingness to follow the attorney's recommendation and the plea decision-making process.

Additionally, the defense attorney's involvement in plea decision-making could be hindered by their client's misunderstanding of their role. For example, defendants who had a greater misunderstanding of the role of defense counsel were less trusting of their attorney (Pierce \& Brodsky, 2002), and may not know to ask their attorneys to inform them about court procedures and/or to collaborate in making case-related decisions (Hoge, Bonnie, Poythress, \& Monahan, 1992; Poythress, Bonnie, Hoge, Monahan, \& Oberlander, 1994; Saxe \& Kuvin, 1974). Defendants' understanding of, and satisfaction with, the process stems from an overall lack of knowledge and information about case adjudication and defense counsels' role (Morgan, 2018). For example, jail-sentenced individuals reported that when their attorneys tried to get them a better plea deal, even if they were unsuccessful, they were more likely to perceive increased procedural fairness and quality of counsel (Morgan, 2018). The attorney's actions and the sense that the attorney was on their side affected defendants' experiences and their ultimate decision to plead guilty. This research points to the importance of defendant-centered representation, focusing on client satisfaction by engaging in rapport- and trust-building interactions (Beeman, 2018). Additionally, the American Bar Association (2015) has placed an emphasis on the defense attorney's role in building an effective-attorney client relationship, through working to establish trust and confidence with the client. Essentially, to provide effective assistance of counsel and assist in the defendant's plea decision-making process, an attorney should establish a relationship of trust and credibility with their client. As the vast majority of criminal convictions are comprised of guilty pleas, examining how attorney credibility affects willingness to follow an attorney's legal counsel and advice is an important consideration. 


\section{Social Influence and Source Credibility}

To guide this research, we used social psychological theories on social influence and source credibility (Cialdini \& Goldstein, 2004; Pornpitakpan, 2004). Social influence involves outside social forces shaping one's own behaviors, cognitions, and attitudes (Cialdini \& Goldstein, 2004). In the context of making important legal decisions, defendants look to their attorney, who has more experience with the legal system, judges, jurors, and knowledge of the law. The degree of influence, however, is likely related to the defendant's perception of their attorney. Research on attitude and persuasion suggests that the decision to follow a source's recommendation is directly related to the perceived credibility of the source (Bannister, 1986), level of trust in the source (Pornpitakpan, 2004), and the perceived power of the source (Linz \& Penrod, 1984; Pornpitakpan, 2004). The source credibility framework focuses on two main components: source expertise and trustworthiness (Pornpitakpan, 2004). Expertise refers to competence and knowledge, whereas trustworthiness refers to honesty and integrity (McGinnies $\&$ Ward, 1980). The effects of source credibility on persuasion are often stronger than other characteristics of the communicator (e.g., likability, attractiveness; see Findley \& Sales, 2012). Because these components (expertise and trustworthiness) have differential importance, it is suggested that these two dimensions be manipulated separately (Pornpitakpan, 2004).

In general, highly credible individuals are more effective at influencing attitudes and inducing persuasion from a recipient than a less credible source (McGinnies, 1968). For example, the more credible the source, the more likely participants were to judge feedback as accurate, to be satisfied with the feedback, and to find the suggestions helpful (Bannister, 1986). Additionally, source credibility was the only significant indicator of participants' intentions to use the source's suggestions/feedback (Bannister, 1986). Willingness to follow a source's 
suggestion is dependent on the source's qualification to offer that recommendation (i.e., expertise). Thus, individuals are attuned to the credibility of a source when evaluating whether or not to follow their recommendation. For attorneys, there are a number of suggested strategies for demonstrating expertise, such as being knowledgeable about the facts of the case and possible defenses, understanding and plainly explaining legal procedural rules, and demonstrating confidence (see Findley \& Sales, 2012, pg. 20).

In addition, high trustworthy sources are more likely to influence attitude change in favor of their message compared to low trustworthy sources (Hovland \& Weiss, 1951). Research suggests trustworthiness may be a more influential component of persuasion. For example, a trustworthy source was more effective regardless of if they were high or low in expertise; the least persuasive source was both low in trustworthiness and expertise (McGinnies \& Ward, 1980). In considering the attorney-client relationship, defendants who trusted their attorneys were more satisfied with their attorneys' performance and the outcome of their case (Boccaccini \& Brodsky, 2002). For attorneys, there are a number of suggested strategies for demonstrating trustworthiness, such as being an active listener, keeping the client informed and involved during the process (Boccaccini \& Brodsky, 2002), asking the client their opinion, and focusing on the client's case during meetings (Campbell, Moore, Maier, \& Gaffney, 2015).

This reliance on trust (as opposed to expertise), can be evident in the example of defendants following the advice of jailhouse lawyers in lieu of counsel provided by their defense attorney (e.g., see Greenfield, 2015). For example, even if a defendant believes the attorney has expertise, they may not trust their attorney, and rather be more willing to follow the advice of jailhouse lawyers, fellow inmates, or family and friends who offer advice based on their own experiences or knowledge acquired through basic legal research (and such bad advice can 
complicate a case) (Greenfield, 2015). If attorneys want to increase defendants' reliance on their own counsel (and minimize defendants' reliance on less qualified individuals), it is important to assess the role of attorney credibility - trust and expertise - in influencing defendant plea decisions. In this context then, it is reasonable to expect that attorney influence on defendant plea decision-making is partially attributable to the attorney's relative power position. However, the defendant's willingness to follow their attorney's recommendation is also dependent upon the degree to which they regard their attorney as credible (trustworthy and a source of expertise).

The practice of law has been described as a "confidence game" (Blumberg, 1967). Defendants' uncertainty and fears about their attorney's expertise and trustworthiness can be important in two key ways: first, how confident a defendant feels in the professional skills and representation capabilities of their attorney; and second, how confident a defendant may feel in their own plea decision-making given a possibly less credible attorney as the source of advice and recommendation (Blumberg, 1967; Flemming, 1986). For example, prior research on plea confidence based on attorney plea recommendations suggests that age (juveniles as opposed to young adults), innocence (as opposed to the guilty), and an attorney's plea label of "really good offer" (as opposed to "fair, but not great") is significantly related to increased confidence in plea decisions (Redlich \& Shteynberg, 2016). The relationship between an attorney's plea recommendation (similar to the "plea label" in Redlich \& Shteynberg, 2016) and their credibility on defendant confidence in plea decisions has yet to be fully examined.

\section{Study Overview}

In this study, we explored the effect of attorney expertise, trustworthiness, and plea recommendation (accept the guilty plea offer vs. reject the guilty plea offer) on plea decisions and ratings of the attorney's influence. We sought to create a more realistic plea-bargaining 
scenario, where refusal of the plea offer did not necessarily equate to trial (i.e., most pleabargaining research has used a plea vs. go to trial model), but rather it could lead to further negotiation. With each plea offer, the defendant is making the decision to accept that offer or reject that offer, which could result in a number of different outcomes (e.g., trial, future plea offer, charges dropped). All participants were told that the prosecutor could come back with another offer, which might be more or less desirable than the current offer, or the prosecutor could fail to bargain in the future (resulting in either no changes to the plea offer or an expiration of a plea deal altogether, with the only remaining alternatives being either a guilty plea to the original charges or going to trial). Participants were then advised by their attorney as to the best course of action.

Our main research question for this project was: How does attorney expertise, trustworthiness, and recommendation affect plea decision-making?

\section{Key Hypotheses}

\section{Willingness to follow attorney advice and plea decision:}

Influence of attorney recommendation. Because research suggests attorney recommendations influence plea decisions (Henderson \& Levett, 2018), we expected to see a main effect of attorney recommendation on participants' willingness to follow the attorney's advice and their final plea decision (our dependent variables). That is, regardless of attorney recommendation (accept vs. reject the guilty plea), we expected participants would be likely to follow the attorney's recommendation, which would be reflected in both participants' willingness to follow attorney advice (variable assessing if the participant's plea decision matches the attorney's recommendation) and their ultimate plea decision (accept the plea offer v. reject the plea offer). 
Influence of attorney trust, expertise, and recommendation. This main effect of attorney recommendation is likely to be qualified by a significant interaction between attorney expertise, trustworthiness, and recommendation. Because research suggests that the least persuasive source is one who is low in both trust and expertise (McGinnies \& Ward, 1980), we expected that participants would be more likely to follow the attorney's recommendation to accept or reject the guilty plea (based on condition) when the attorney was high in expertise and/or high in trustworthiness compared to low in both expertise and trustworthiness.

\section{Confidence ratings:}

Influence of attorney trust and expertise. Because a defendant's evaluation of their attorney's level of skill likely contributes to their confidence in the attorney and decisions (Blumberg, 1967; Flemming, 1986), we expected that attorney expertise and trustworthiness would affect confidence in decision ratings (our dependent variable), which would be demonstrated by a significant interaction between attorney expertise and attorney trustworthiness. Importantly, we expected this effect to be present regardless of attorney recommendation (accept guilty plea v. reject guilty plea). That is, regardless of attorney recommendation, we expected participants would be more confident in their decision when the attorney was high in expertise and/or high in trustworthiness compared to low in expertise and low in trustworthiness.

\section{Influence of attorney scales:}

Influence of attorney trust and expertise. Similarly, we expected attorney expertise and trustworthiness would affect participants' ratings of the attorney (our dependent variables), which would be demonstrated by a significant interaction between attorney expertise and attorney trustworthiness. That is, participants would rate the influence of the attorney and their 
overall perception of the attorney higher in conditions where the attorney was high in expertise and/or high in trustworthiness compared to low in both expertise and trustworthiness. However, as research has suggested trustworthiness as being a stronger component of a persuasive source than expertise (McGinnies \& Ward, 1980), it is possible that only attorney trustworthiness would affect ratings of the attorney (which would be demonstrated by a main effect of attorney trustworthiness).

\section{Method}

Design. We used a 2 (expertise: high vs. low) X 2 (trustworthiness: high vs. low) X 2 (attorney recommendation: accept the plea offer vs. reject the plea offer) between subjects factorial design.

Participants and power. We determined sample size by conducting a power analysis using $\mathrm{G}^{*}$ Power 3.1 (Faul, Erdfelder, Lang, \& Buchner, 2009). We used a small effect size for ANOVA analyses $(f=.20)$, with $\alpha=.05$, and power $=.80$ (recommended by Cohen, 1988). Using these criteria, we needed at least 199 participants (roughly 25 per cell). We increased the estimated sample size to account for any possible interaction effects. Participants were ineligible to participate in this study if they completed the pilot study (more detail below).

Participants were 593 individuals recruited from Amazon’s Mechanical Turk (MTurk) worker pool. We compensated participants $\$ 1.50$ for their participation. Because the study was conducted online, two attention check questions were included in addition to manipulation check questions (information included below). Participants were excluded from analysis if they answered either of the attention check questions incorrectly $(N=39)$, indicating that they did not read stimulus materials carefully. Our sample consisted of the remaining 554 participants. 
The average age for the sample was 37 years old (range $19-71$ years old). The sample was $46.4 \%$ male, $52.3 \%$ female, and $0.7 \%$ transgender ( 2 participants, $0.7 \%$, preferred not to answer or did not respond). The majority of participants were White $(80.5 \%)$, followed by Black/non-Hispanic (6.6\%), Asian (7.6\%), Hispanic (4.0\%) and other (1.3\%). Highest obtained education level varied across participants; $10.3 \%$ earned a high school degree, $24.2 \%$ attended some college, $13.3 \%$ earned an associate's degree or technical college degree, $38.1 \%$ earned a bachelor's degree, $2.3 \%$ attended some graduate school, and $11.6 \%$ earned a graduate degree ( $0.3 \%$ preferred not to answer). Also, $14.9 \%$ of participants had been involved with the criminal justice system, $82.5 \%$ had not, and $2.6 \%$ preferred not to answer.

Because the hypothetical plea scenario used in this study involved a DWI/DUI offense (more below), we asked participants questions related to their drinking and risky driving behavior. We asked participants if they or someone they knew had ever been pulled over for drinking and driving; $47.7 \%$ indicated 'no' and 49\% had been pulled over themselves or knew some who had (3.3\% failed to respond or preferred not to answer). Similarly, participants were asked if they or someone they knew had ever been convicted of a drinking and driving offense; $50.7 \%$ indicated 'no' and $46.7 \%$ had been convicted themselves or knew some who had $(2.6 \%$ failed to respond or preferred not to answer).

Pilot study. To create study materials, we conducted a pilot study to operationalize the manipulated variables of trustworthiness and expertise. The goal of this pilot study was to identify indicators of an attorney's level of trustworthiness and expertise (these items were based on prior research; for example, Beeman, 2018; Boccaccini \& Brodsky, 2002; Campbell et al., 2015; Findley \& Sales, 2012). In total, 54 participants participated in the pilot study. Participants answered a questionnaire assessing indicators of trustworthiness and expertise on ranked items 
and open-ended questions (qualitative responses were largely consistent with quantitative items). The top 4 ranked items were used to create the manipulated information included in the hypothetical scenario to indicate high versus low trustworthiness and expertise (see Tables 1 and 2 for items and ranking scores).

Hypothetical Plea Scenario. In this study, participants read a hypothetical plea scenario (see Appendix). Participants were told to imagine themselves as a defendant who had been charged with one count of driving while under the influence (hypothetical scenario details were taken directly from information on plea offers in a drunk-driving case; http://dui.findlaw.com/dui-charges/the-tale-of-two-drunk-driving-cases.html). Ultimately, a DWI/DUI, as presented in this hypothetical offers a relatively realistic offense that individuals might not have as much difficulty envisioning themselves, or someone they know, being pulled over for and arrested (e.g., overestimating level of sobriety after drinking one or two alcoholic beverages, miscalculation of BAC level; see above for participants' responses to the frequency of these events having occurred to themselves or someone they know).

Participants were given details of the incident and were told they had been formally charged. Participants read that they completed field sobriety and breathalyzer tests at the scene; while they passed the field sobriety test, their blood alcohol concentration (BAC) was 0.10, above the legal limit of 0.08 . Just before arraignment, the defendant met with their defense attorney to discuss the case and their concerns, and then inquired about the attorney's experience overall and with these types of cases (the attorney's response varied based on condition). At arraignment, the judge determined the defendant was not a flight risk, and they were released on their own recognizance with instructions to return three weeks later for a possible plea hearing. The attorney promised to keep the defendant updated with phone calls and/or emails throughout 
the three-week time period, and depending on the condition, the attorney did or did not. The defendant received a phone call from their attorney three days before the court date, in which the defense attorney discussed aspects of the case, plea offer, and gave a plea recommendation to either accept or reject the plea offer (varied based on condition). The plea offer remained constant across conditions. Manipulations within the hypothetical scenario were the attorney's level of expertise and trustworthiness (manipulated through information shared with the defendant), and the attorney's plea recommendation (which was explicitly stated). Expertise and trustworthiness manipulations were informed based on pilot study rankings.

Regarding the defense attorney's experience and knowledge of the legal options and possible consequences; in high expertise conditions, the defense attorney was informed of the specific circumstances of the case and conveyed familiarity with legal options and consequences for DUI/DWI offenses. In low expertise conditions, the attorney was not informed of the specific circumstances of the case, stated that they have not handled as many of these types of cases and were not entirely familiar with the law in this jurisdiction and potential consequences.

In high trustworthiness conditions, the attorney maintained regular contact, seemed dependable, and did what they said they would (e.g., emails back and forth with the defendant and called to discuss options). Furthermore, the defense attorney was honest with the defendant about potential consequences. In low trustworthiness conditions, the defense attorney did not seem dependable, as they had not replied to the defendant's emails or phone calls, despite having promised to do so. And although the defense attorney said they were honest about potential consequences, the defendant is told they do not believe that to be true. 
All participants were told that it is unknown if the prosecutor would come back with a better offer, worse offer, or fail to bargain again. The defense attorney then reiterated the plea recommendation (to accept the plea vs. reject the plea).

\section{Dependent variables.}

Plea decision and confidence ratings. Participants made a plea decision (waive their rights and accept the guilty plea offer vs. reject the guilty plea offer and prepare for trial with possibility of future better, worse, or no other offer from the prosecutor) and rated how confident they were in their decision on a scale from 0-100\%. Similar plea confidence scales have been used successfully in prior research (see Redlich \& Shteynberg, 2016).

Motivation rankings. Participants ranked the motivations from MOST important factor to LEAST important factor in their plea decision. These motivations were informed by pilot study responses and research on plea decisions (Bordens \& Basset, 1985; Malloy et al., 2014; Redlich \& Shteynberg, 2016). Items appeared in random order to control for order effects. For those who accepted the plea, the following options were ranked: (a) plea offer was reasonable; (b) my attorney's recommendation; (c) going to trial would be too risky; (d) I am concerned a better plea offer wouldn't come along; (e) this was the best option; and (f) the punishment at trial might be more severe. Those who rejected the guilty plea ranked the following options: (a) plea offer was unreasonable; (b) my attorney's recommendation; (c) I could be found not guilty at trial (acquitted); (d) a better guilty plea offer could come along; (e) this was the best option; and (f) thinking of the long-term consequences of accepting a guilty plea.

Qualitative responses. Immediately after entering their plea decision, participants were asked to explain the reason for their plea decision. Additionally, after making a plea decision, explaining their rationale, and then ranking the motivations that contributed to their decision, 
participants answered the open-ended question, 'Can you think of any other reasons why you chose to plead guilty [or reject the guilty plea]?'

Influence of attorney scales. Participants indicated agreement with a series of statements on 6-point Likert-type scales with 1 indicating 'strongly disagree' and 6 indicating 'strongly agree;' items followed by an (R) are reverse coded. Items were analyzed in an exploratory factor analysis using maximum likelihood extraction and varimax rotation. Items loaded on to two main factors. We combined items into two scales by averaging item scores: (1) influence of the attorney (eigenvalue $=1.22$ ) and $(2)$ overall perception of their attorney (eigenvalue $=6.63$ ). Responses to items were averaged to create an 'influence of the attorney' scale $(\alpha=0.90)$ : (a) my attorney's advice did not influence my decision (R); and (b) my attorney's advice influenced my decision. Responses to items were averaged to create an overall 'overall perception of the attorney' scale $(\alpha=0.96)$ : (a) my attorney provided well-reasoned advice; (b) my attorney gave good advice; (c) I believe my attorney possessed the necessary ability to do his/her job successfully; (d) I believe my attorney possessed the necessary knowledge to do his/her job successfully; (e) I believe my attorney possessed the necessary skill to do his/her job successfully; (f) my attorney's advice was not helpful (R); (g) my attorney was dependable; and (h) my attorney did not do what they said they would (R).

Demographic information. Participants indicated their age, gender, racial/ethnic background, and highest level of education. Due to the nature of our hypothetical scenario, we asked participants questions regarding if they have a driver's license, traffic violation history, and their driving and drinking behaviors (questions taken from Schechtman, Shinar, \& Compton, 1999; Schroeder, Meyers, \& Kostyniuk, 2013). For example, 'Have you or someone you know ever been pulled over for drinking and driving over the legal limit (BAC > .08)?' Participants 
could skip these questions or indicate 'prefer not to answer.' We examined the effect of prior involvement with the criminal justice system, having been pulled over themselves or knowing someone who has for drinking and driving over the legal limit, and having been convicted or knowing someone who has for a DUI/DWI offense on final plea decision. None of the models were significant; prior involvement, $\chi^{2}(1)=0.76, p=.384$; being pulled over, $\chi^{2}(1)=0.17, p=$ .681 ; convicted, $\chi^{2}(1)=0.03, p=.864$. More information on participants' responses to these questions can be obtained upon request to the first author.

Manipulation checks. Attention to the attorney's recommendation was measured by the following question: Your attorney advised you to do which of the following? (accept the plea vs. reject the plea). Attention to the attorney's level of expertise was measured by asking the following true vs. false questions: (a) your attorney specifically told you they had handled a lot of drinking and driving cases (similar type of cases); (b) your attorney said they are not very familiar with the law in this particular jurisdiction for these types of cases. And, attention to the attorney's level of trustworthiness was measured by asking the following true vs. false questions: (a) you have regular contact with your attorney; that is, you have emailed back and forth and they have called you to discuss case matters; (b) your attorney told you how they have tried to be very transparent and honest with you about all possibilities (potential consequences). And according to the hypothetical scenario, you do believe them. To be included in the final analysis sample, participants must have correctly answered all five manipulation checks questions (based on their condition). The final analysis sample included 302 participants.

We conducted analyses with the full sample (including participants who failed manipulation checks) and a different exclusion criteria sample (participants who correctly answered 1 question assessing each of our manipulations). The results trended in the same 
direction.

Procedure. The University Institutional Review Board approved all materials and procedures prior to the collection of these data. Participants signed up for the study online through Amazon's Mechanical Turk (MTurk) website and were directed to the Qualtrics website to complete the study. After indicating consent, participants read the hypothetical plea scenario (randomly assigned to condition) and answered a questionnaire. The questionnaire assessed participants' plea decision, confidence in their decision, ratings of their attorney, and factors that influenced their decision. After which, participants were compensated.

\section{Results}

Overall, $82.5 \%$ of participants accepted the guilty plea offer and waived their right to trial, while $17.5 \%$ rejected the plea offer. We began by examining the percentage of participants who followed the attorney's recommendation (regardless of trust and expertise). We ran a Pearson's chi-square test to examine the association between attorney recommendation and final plea decisions; the association was significant, $\chi^{2}(1)=21.40, p<.001$. Of participants whose attorney recommended accepting the guilty plea, $91.0 \%$ followed that recommendation, while $9 \%$ did not (rejected the plea). Of participants whose attorney recommended rejecting the guilty plea, $29.6 \%$ followed that recommendation, while $70.4 \%$ did not (accepted the guilty plea).

To examine factors that influenced willingness to follow the attorney's recommendation, we created a new variable- "willingness to follow attorney advice", coded as either "did follow the attorney's recommendation' or 'did not follow the attorney's recommendation.' We ran a backwards stepwise logistic regression to test the effect of attorney trustworthiness, expertise, recommendation, and their interaction on participants' willingness to follow the attorney's advice. The overall model was significant, $\chi^{2}(2)=137.34, p<.001$. 
There were significant main effects of trustworthiness, $B=0.92, S . E=0.34$, Wald's $\chi^{2}=$ 7.36, $p=.007, \exp (B)=2.51,95 \% C I[1.29,4.86]$, and attorney recommendation, $B=3.27$, S.E $=0.34$, Wald's $\chi^{2}=91.80, p<.001, \exp (B)=26.42,95 \% C I[13.52,51.62]$. All other effects were not included in the final model. Participants were more likely to follow the attorney's advice in high trustworthiness conditions $(M=0.65)$ compared to low trustworthiness conditions $(M=0.53)$. Additionally, participants were more likely to follow the attorney's advice when the attorney recommended accepting the guilty plea $(M=0.89)$ compared to rejecting the guilty plea $(M=0.28)$.

\section{Effect of Attorney Expertise, Trust, and Recommendation}

Plea Decisions. To examine the effect of attorney trustworthiness, expertise, recommendation, and their interaction on participants' plea decisions, we first ran a backwards, stepwise logistic regression. The overall model was significant, $\chi^{2}(2)=29.07, p<.001$. There was a significant main effect of attorney trustworthiness on plea decisions. However, this main effect was qualified by a significant interaction between trustworthiness and attorney recommendation, $B=2.27, S . E=0.48$, Wald's $\chi^{2}=22.20, p<.001, \exp (B)=9.72,95 \% C I$ $[3.77,25.03]$. All other effects were not included in the final model.

We probed the interaction using Process macro in SPSS. When the attorney recommended accepting the guilty plea, those participants in high trustworthiness conditions were more likely to plead guilty $(M=0.94)$ compared to participants in low trustworthiness conditions $(M=0.84), B=1.22, S . E=0.54, z=2.25, p=.024$. When the attorney recommended rejecting the guilty plea, the effect of trustworthiness was not significant $\left(M_{\text {high }}=0.65 \mathrm{vs} . M_{\text {low }}=\right.$ $0.79), B=-0.72, S . E=0.43, z=-1.68, p=.093$. 
Confidence Ratings. We then ran an ANOVA to test the effect of attorney

trustworthiness, expertise, recommendation, and their interaction on participants' confidence in their plea decision. There was a main effect of expertise at the traditional level of significance cut-off point $(\mathrm{p}<.05), F(1,294)=3.74, p=.054, \eta^{2}=.01$. Participants were more confident in their decision in high expertise conditions compared to low expertise conditions, $M_{h i g h}=76.96$, $S D=20.28, S E=1.86, M_{l o w}=71.82, S D=23.93, S E=1.90, d=0.23,95 \% C I[0.01,0.46]$. All other effects were not significant, $p s>.077$.

Influence of Attorney Scales. Because the two attorney scales (influence of the attorney and overall perception of the attorney) were moderately correlated with each other (Pearson's $r=$ 0.52), we ran a MANOVA including these scales as the dependent variables and attorney trustworthiness, expertise, recommendation, and their interaction as the independent variables. At the multivariate level, there were significant main effects of trustworthiness, expertise, and attorney recommendation.

These main effects were qualified by a significant interaction between attorney trustworthiness and recommendation, $\lambda=.98, F(2,290)=3.06, p=.049, \eta^{2}=.02$. The interaction effect was significant for participants' overall perception of the attorney ratings, $F$ (1, $291)=4.20, p=.041, \eta^{2}=.01$. In conditions where the attorney recommended accepting the guilty plea, there was a simple main effect of attorney trustworthiness, $p<.001$. When the attorney recommended accepting the guilty plea, participants rated their overall perception of the attorney higher when the attorney was high in trustworthiness compared to low in trustworthiness, $M_{\text {high }}=4.71, S D=0.92, S E=0.09, M_{\text {low }}=3.17, S D=1.27, S E=0.12, d=1.46$, $95 \% C I[1.11,1.80]$. The simple main effect of attorney trustworthiness was also significant in conditions where the attorney recommended rejecting the guilty plea, $p<.001$. When the 
attorney recommended rejecting the guilty plea, participants rated their perception of the attorney higher when the attorney was high in trustworthiness compared to low in trustworthiness, $M_{\text {high }}=$ 4.06, $S D=1.14, S E=0.11, M_{\text {low }}=3.00, S D=1.03, S E=0.14, d=0.96,95 \% C I[0.58,1.35]$.

The interaction effect of attorney trustworthiness and recommendation was not significant for participants' influence of the attorney ratings, $F(1,291)=0.12, p=.731, \eta^{2}=$ .000 .

At the multivariate level, the interaction effect of attorney trustworthiness and attorney expertise was at the traditional level of significance cut-off point, $\lambda=.98, F(2,290)=2.96, p=$ $.053, \eta^{2}=.02$. However, the effect was not significant at the univariate level; influence of attorney, $F(1,291)=2.28, p=.132, \eta^{2}=.008$, and overall perception of the attorney, $F(1,291)$ $=1.11, p=.294, \eta^{2}=.004$. All other effects were not significant, $p \mathrm{~s}>0.28$. $^{1}$

\section{Motivation for Plea Decision Rankings}

Participants were asked to rank motivations for their plea decision; these motivations were informed by prior self-report research on plea decisions and the hypothetical scenario in this study. Mean ranking scores are listed with each item (ranging from 1-6); lower scores indicate that the item was more important in the participant's plea decision-making. In exploring motivations for rejecting the guilty plea, factors are ranked from most important factor to least important factor: (1) a better guilty plea offer could come along $(M=2.62)$; (2) I could be found not guilty at trial (acquitted) $(M=3.13)$; (3) thinking of the long-term consequences of accepting a guilty plea $(M=3.32)$; (4) my attorney's recommendation $(M=3.66)$; (5) plea offer was

\footnotetext{
${ }^{1}$ We conducted exploratory analyses of the effect of gender on our key DVs. There was a significant multivariate effect of gender on attorney ratings, $\lambda=.97, F(2,292)=4.25, p=.015, \eta^{2}=.03$. Males rated the attorney as more influential $(M=3.76)$ compared to females $(M=3.26), F(1,293)=7.70, p=.006, \eta^{2}=.03$. And males rated their overall perception of the attorney as higher $(M=4.18)$ than females $(M=3.83), F(1,293)=5.17, p=.024, \eta^{2}=.02$. In this sample, there was not enough variation to conduct any analyses exploring the effect of participant race on key DVs (i.e., our sample was $76 \%$ White).
} 
unreasonable $(M=3.68)$; and $(6)$ this was the best option $(M=4.58)$. In exploring motivations for accepting the guilty plea, factors are ranked from most important factor to least important factor: (1) plea offer was reasonable $(M=2.60)$; (2) the punishment at trial might be more severe $(M=2.82)$; (3) going to trial would be too risky $(M=3.42)$; (4) I am concerned a better plea offer wouldn't come along $(M=3.56)$; (5) this was the best option $(M=3.77)$; and (6) my attorney's recommendation $(M=4.83)$.

\section{Summary of Qualitative Plea Motivation Responses}

Two independent, graduate research assistants, blind to condition, coded participants' responses to the question assessing the motivation for their plea decision. Overall, agreement between coders was good (ranging from $0.681-0.977$ ). See Table 3 for an overview of themes, corresponding coder-agreement values, and percentage of participants who indicated particular themes in their responses. The most common themes were: that the plea was a good deal (24.80\%), to avoid punishment $(22.80 \%)$, that they were guilty of the crime $(21.50 \%)$, desire to avoid more severe consequences (16.20\%), defense attorney - negative (8.90\%), evidence against them (8.30\%), and willingness to accept fault/culpability (7.90\%). More information on qualitative responses can be obtained upon request to the first author.

\section{Discussion}

The goal of this project was to examine the influence of attorney characteristics and recommendation on defendant plea decision-making. To do this, we first explored indicators of defense attorney trustworthiness and expertise. That is, what types of statements or actions are most influential in demonstrating expertise and establishing a relationship of trust for clients in regard to their attorney? In rating defense attorney expertise, the top-rated items were that the attorney seemed familiar with the law in that jurisdiction (place-specific knowledge), knew the 
legal options and consequences for this type of crime (subject-matter knowledge), was informed of the facts of the case (case-based knowledge), and had experience with these types of cases (experience-based knowledge). In rating attorney trustworthiness, the top-rated items were that the attorney does what they say they will (dependable), is honest with the client about potential consequences (transparent), seems to tell the truth (honest), and has regular communication with the client (communicative). We then explored how varying levels of expertise and trust influenced defendants' willingness to follow the attorney's plea recommendation.

\section{Willingness to Follow Attorney Advice and the Ultimate Plea Decision}

We expected that the attorney's recommendation would affect participants' willingness to follow the attorney's advice (variable assessing if participant's plea decision matches the attorney's recommendation) and their plea decision (accept the plea offer v. reject the plea offer). However, we expected this main effect would be qualified by source credibility factors (Hypothesis 1). That is, participants would be more likely to follow the attorney's recommendation when their attorney was high in trustworthiness and/or expertise compared to low in trustworthiness and expertise. We found partial support for this hypothesis.

Willingness to Follow Advice. In this study, we found that the attorney's recommendation and trustworthiness affected willingness to follow the attorney's advice. Participants were more likely to follow the attorney's advice when the attorney was high in trustworthiness compared to low in trustworthiness. Additionally, participants were more likely to follow the attorney's advice when the attorney recommended accepting the guilty plea compared to rejecting the guilty plea. Participants were roughly three times more likely to follow the attorney's advice when their attorney recommended accepting the guilty plea offer compared to rejecting the guilty plea offer; in this study, $91 \%$ of participants advised to accept the guilty 
plea followed that advice, whereas only $29.6 \%$ of participants advised to reject the guilty plea followed that advice. While there were main effects of attorney recommendation and trustworthiness on willingness to follow the attorney's advice, there were no significant interaction effects.

Plea Decision. There was a significant interaction between trustworthiness and attorney recommendation on participants' plea decisions. Participants whose attorney recommended accepting the guilty plea were more likely to do so when their attorney was high in trustworthiness compared to low in trustworthiness. This finding builds upon other work (Henderson \& Levett, 2018), which suggests the content of the attorney's recommendation influences decisions. In this study, we found that not only does the content of the recommendation matter, characteristics of the source of that recommendation matter as well (but only in some recommendation conditions). For those participants whose attorney recommended rejecting the guilty plea, the effect of attorney trustworthiness was not significant. In effect, the attorney's level of trustworthiness and expertise did not matter for those defendants advised to reject the guilty plea. And, as pointed out above, the vast majority of those participants went against that recommendation and pleaded guilty. In this study, roughly two-thirds of participants advised to reject the guilty plea went against their attorneys' recommendation and pleaded guilty. This is an important finding, in that participants were more willing to accept the guilty plea, even when it was against the advice of their attorney.

Past research examining defense attorney plea decision-making using a hypothetical scenario found that defense attorneys often make recommendations that are against their client's stated wish (likely due to weighing of legally relevant variables; Kramer, Wolbranksky, Heilbrun, 2007). We found that defendants go against the attorney's stated recommendation in 
some conditions; future research could tease out this finding by examining this from the defendant's perspective. That is, exploring the defendant's decision-making process when they choose to go against their attorney's recommendation. This is counter-intuitive to the principles of social influence (Cialdini \& Goldstein, 2004), which would suggest defense attorneys, due to their position, would have a strong influence on defendant decision-making.

Other plea decision-making research has found the effect of social influence to be more pervasive in some populations compared to others (Henderson \& Levett, 2018). Similarly, in this study, the social influence of the attorney's recommendation was not as impactful on plea decisions when the attorney advised the defendant to reject the guilty plea. These findings suggest a natural bias (or tendency) towards plea bargaining, especially in lower level crimes, such as the one presented in our hypothetical scenario. It is likely the nature of our scenario can help explain some of these patterns (more detail below), but these findings represent an area for future research to examine.

Past research has pointed to the influence of credibility on attitude change and persuasion (McGinnies, 1968), we did not see the expected effect of attorney expertise on plea decisions. In this study, we saw stronger support for the trustworthiness component of credibility for influencing willingness to follow the attorney's advice, and ultimate plea decision. This is consistent with past work, suggesting that the source's level of trustworthiness can be more influential than expertise (McGinnies \& Ward, 1980). In some circumstances, low-credibility communicators can be more effective than high credibility communicators (Sternthal, Dholakia, \& Leavitt, 1978), which could explain our lack of findings for expertise on our main dependent measure - plea decision. When the source's information is similar to the receiver's initial opinion/position, credibility of the communicator is not as influential (Bochner \& Insko, 1966). 
It could be that participants in our study were initially inclined to accept the guilty plea, and therefore the attorney's level of expertise did not have the intended effect. Future research could measure participants' initial disposition towards accepting the plea offer versus going to trial (or taking a chance on future plea offers) to examine the role of initial opinions and attitude change.

\section{Plea Decision Confidence}

We expected that regardless of recommendation, attorney expertise and trustworthiness would affect participants' confidence in their decision (Hypothesis 2). That is, we did not expect the content of the attorney's recommendation would lead participants to feel more or less confident in their decision, but we did expect that those defendants represented by an attorney high in trustworthiness and/or expertise would feel more confident in their decision than those whose attorney was low in trustworthiness and expertise. We found partial support for this hypothesis.

Attorney expertise influenced participants' confidence in their decision $(p=0.054)$, but there was no effect of trustworthiness on confidence; participants whose attorney was high in expertise were more confident in their decision than those whose attorney was low in expertise. In terms of source credibility factors, we found that attorney expertise played more of a role in participant's confidence in their decision (regardless of trustworthiness), but attorney trust played more of a role in the decision to follow the attorney's advice and ultimate plea decision (regardless of expertise).

\section{Influence of the Attorney}

We expected attorney expertise and trustworthiness would affect participants' ratings of the attorney (Hypothesis 3). That is, we hypothesized that those defendants represented by an attorney high in trustworthiness and/or expertise would rate the influence of the attorney and 
their overall perception of the attorney higher (more positively) than those whose attorney was low in trustworthiness and expertise. Based on an exploratory factor analysis, we created an influence of the attorney (i.e., how strongly the attorney influenced the participant's decision) and overall perception of the attorney scales (i.e., the attorney gave well-reasoned advice, possessed ability, skill, and knowledge to do the job, was dependable, and helpful). While we did find main effects of attorney trustworthiness and expertise, these effects were qualified by a significant interaction. Somewhat in line with our hypothesis, participants whose attorney was high in trustworthiness rated their overall impression of the attorney more positively than those whose attorney was low in trustworthiness (in both accept and reject recommendation conditions). However, this effect of was not significant for influence of the attorney ratings. Nor, did we see the expected effect of attorney expertise on ratings of the attorney.

\section{Plea Decision Motivations}

While attorney expertise, trustworthiness, and recommendation influenced participants' plea decisions (trust $\mathrm{X}$ recommendation), confidence in decision (expertise), and ratings of the attorney (trust $\mathrm{X}$ recommendation), we did not see this same effect evidenced in participants' motivation rankings or qualitative responses. That is, participants who rejected the guilty plea ranked the attorney's recommendation as the $4^{\text {th }}$ most important factor in their decision-making and those who accepted the guilty plea ranked the attorney's recommendation as $6^{\text {th }}$ (last). In our qualitative data, only $17 \%$ of participants referenced the defense attorney as a motivating factor for their plea decision. Instead, participants noted that the plea offer was reasonable, trial was riskier, and the punishment at trial could be more severe as the most important factors weighing into the decision to accept the guilty plea (motivation rankings). In addition, referencing one's actual guilt and the desire to avoid punishment and more severe consequences, were the top 
motivations for decision-making (qualitative responses). This is somewhat consistent with past research suggesting that willingness to plead guilty is motivated by instrumental reasons, such as desire to resolve the matter quicker and the punishment differential between the plea offer and possible trial sentence (Bordens \& Bassett, 1985; Malloy et al., 2014).

On the one hand, it is possible that attorney recommendation did not have as much of a perceived influence because it was clear that the defendant [participant] was guilty of the crime (i.e., we did not manipulate the guilt of the participant). That is, past research suggests attorney recommendation has a stronger effect on innocent individuals' decisions compared to guilty individuals (Henderson \& Levett, 2018). Research also suggests that guilty individuals are more risk-averse in their plea decisions than innocent individuals (Tor, Gazal-Ayal, \& Garcia, 2010). In our study, roughly a quarter of participants responded that their guilt was a factor influencing their plea decision (e.g., “...I am guilty, I did drive home drunk and did not pay attention. I should accept the consequences"). Similar to Tor and colleagues (2010), it could be that participants were less willing to go to trial (supported by our high overall plea acceptance rate), and therefore the social influence of the attorney was not as strong of a motivating factor. On the other hand, it could be that participants were not cognizant enough to pick-up on the attorney's actual influence on their plea decision. Although few participants ranked their defense attorney as a motivating factor in their plea decision, we saw that the attorney's level of trustworthiness and the content of their recommendation did affect willingness to follow their advice and overall plea decision (although this was not significant for participants advised to reject the plea).

\section{Future Directions and Limitations}

This study contributes to our understanding of how characteristics of the attorney affect the social influence of an attorney's recommendation, and what this means for the attorney-client 
relationship and plea negotiations/decisions. These contributions, however, should be considered in light of few limitations.

In our hypothetical scenario, it was clear that the defendant [participant] was guilty of drinking and driving (the crime they were accused of). Future research should replicate and extend these findings by including both innocent and guilty conditions. For example, would innocent individuals be susceptible to the social influence of an attorney even if the attorney was low in trustworthiness or expertise? While our study contributes to research examining the causal relationship of attorney plea recommendations on decisions, future research should consider how these effects might differ as a result of the defendant's actual guilt or innocence.

Future work could also build upon this study by examining variations in the influence of attorney recommendation and source credibility factors within different populations and other crime types. For example, how the attorney's level of trustworthiness, expertise, and their plea recommendation influence decision-making for susceptible populations (e.g., juveniles, individuals with intellectual disabilities and mental illness). In our study, overall guilty plea acceptance rates were relatively high (although comparable to rates in the U.S. criminal justice system), future research could consider a different context so as to understand and contextualize greater variation between groups. For example, future research could vary the severity of the crime, plea discount, and strength of the evidence in the case, and examine if these legally relevant factors interact with the attorney's influence/recommendation. To separate the findings that could be attributed from study design alone, future research should utilize a variety of hypothetical case scenarios and also examine the role of attorney advice/recommendation in court settings through observational and ethnographic study designs. 
It is also possible the attorney's gender could moderate the effect of source credibility factors. For example, in one study, across all measures of an expert witness (likability, believability, trustworthiness, confidence, and credibility), male experts were rated more positively than female experts (Larson \& Brodsky, 2010). However, in another study, there was no difference in attorney-client trust scores between those clients represented by a female attorney and those represented by a male attorney (Boccaccini \& Brodsky, 2002). The materials used in our study did not include any information regarding the attorney's gender, so as to remain neutral, but future research could explore this potential effect.

The experimental approach used to address our research question comes with advantages (increased control and ability to make causal predictions), however it does come with limitations. Namely, low ecological validity. In this study, we used a written scenario; therefore, we did not capture the seriousness of this decision (and the real consequences) that defendants in the criminal justice system are facing. Additionally, our sample is not reflective of the racial composition of the criminal justice system (https://ucr.fbi.gov/crime-in-the-u.s/2016/crime-inthe-u.s.-2016/topic-pages/tables/table-21). While this sample comes with its limitations, Amazon Mturk is recognized as a diverse sample and is more generalizable to the greater population than traditional student populations (Sheehan, 2018), and can be as valid as other alternative methods (Hauser, Paolacci, \& Chandler, 2018), especially when best practices are followed to ensure data validity (Sheehan, 2018). We restricted eligible geographical regions to the U.S., used a high HIT approval rating, included both attention and manipulation check questions, and excluded participants who had completed our past work (i.e., the pilot study). However, it is important to consider the limitations of this sample in interpreting the results.

\section{Conclusion}


Scholars have called for greater attention to be given to the psychological influences that affect defendant plea decisions (see e.g., Bibas, 2004; Redlich et al., 2017). One psychological factor to consider is the social influence of the defense attorney on defendant decision-making. Research suggests defendants are influenced by their attorney's recommendation, but this influence is likely dependent upon the defendant's perception of their attorney. Exploring how attorneys convey trustworthiness and expertise, and how these factors influence willingness to follow their recommendation, is an important contribution to our understanding of defendant plea decisions. In this study, we found that defendants are attuned to the attorneys' level of trustworthiness and expertise, although with differing effects. The attorney's level of trust (high) played a role in defendants' willingness to follow the attorney's advice and plea decisions, while the attorney's level of expertise (high) played a role in defendants' overall confidence in their decision. This attention to attorney interpersonal skills further supports a more defendantcentered approach to lawyering (Beeman, 2018), where emphasis is placed on rapport- and trustbuilding. This study contributes to our knowledge of how defense attorneys influence plea decisions by demonstrating that individuals are responsive to interpersonal skills when assigning weight to their attorney-client experience.

\section{Declaration of Interest Statement}

The authors report no potential conflicts of interest. 


\section{References}

Alschuler, A. W. (1975). The defense attorney's role in plea bargaining. The Yale Law Journal, 84(6), 1179-134. Retrieved from https://chicagounbound.uchicago.edu/cgi/viewcontent.cgi?article=1981\&context=journal _articles

American Bar Association (2015). ABA criminal justice standards for the defense function, $4^{\text {th }}$ ed. Retrieved from https://www.americanbar.org/groups/criminal_justice/standards/DefenseFunctionFourthE dition.html\#1.2

Bannister, B. D. (1986). Performance outcome feedback and attributional feedback: Interactive effects on recipient responses. Journal of Applied Psychology, 71(2), 203-210. http://dx.doi.org/10.1037/0021-9010.71.2.203

Beeman, M. (2018). National indicators of quality indigent defense. Washington, DC: National Legal Aid \& Defender Association. Retrieved from http://www.nlada.org/sites/default/files/pictures/2018-0308\%20Quality\%20Indicators\%20Project\%20covered.pdf

Bibas, S. (2004). Plea bargaining outside the shadow of a trial. Harvard Law Review, 117, 24632547. doi:10.2307/4093404

Blumberg, A. (1967). The practice of law as a confidence game: Organizational cooptation of a profession. Law and Society Review, 1(2), 15-40. doi:10.2307/3052933

Boccaccini, M. T. \& Brodsky, S. L. (2002). Attorney-client trust among convicted criminal defendants: Preliminary examination of the attorney-client trust scale. Behavioral Sciences and the Law, 20, 69-87. DOI: 10.1002/bsl.469 
Bochner, S., \& Insko, C. A. (1966). Communicator discrepancy, source credibility, and opinion change. Journal of Personality and Social Psychology, 4(6), 614-621. http://dx.doi.org/10.1037/h0021192

Bordens, K. S. \& Bassett, J. (1985). The plea bargaining process from the defendant's perspective: A field investigation. Basic and Applied Social Psychology, 6(2), 93-110. https://doi.org/10.1207/s15324834basp0602_1

Boykin v. Alabama, 395 U.S. 238 (1969)

Brady v. United States, 397 U.S. 742, 756-58 (1970)

Brewer v. Williams, 430 U.S. 387 (1977)

Campbell, C. M., Moore, J., Maier, W., \& Gaffney, M. (2015). Unnoticed, untapped, and underappreciated: Clients' perceptions of their public defenders. Behavioral Sciences and the Law, 33(6), 751-770. doi:10.1002/bs1.2182

Cialdini, R. B. \& Goldstein, N. J. (2004). Social influence: Compliance and conformity. Annual Review of Psychology, 55, 591-621. doi: 10.1146/annurev.psych.55.090902.142015

Cohen, J. (1988). Statistical power analysis for the behavioral sciences (2nd ed.). New Jersey: Lawrence Erlbaum.

Cohen, T. H., \& Reaves, B. A. (2006). Felony defendants in large urban counties, 2002. Washington, DC: U.S. Department of Justice, Office of Justice Programs, Bureau of Justice Statistics. Retrieved from https://www.bjs.gov/content/pub/pdf/fdluc09.pdf

Devine, D. J., Clayton, L. D., Dunford, B. B., Seying, R., \& Pryce, J. (2001). Jury decision making: 45 years of empirical research on deliberating groups. Psychology, Public Policy, and Law, 7(3), 622-727. DOI: 10.1037//1076-8971.7.3.622

Durose, M. R. \& Langan, P. A. (2007). Felony Sentences in State Courts, 2004. Bureau of 
Justice Statistics Bulletin. Retrieved from

https://www.bjs.gov/content/pub/pdf/fssc04.pdf

Faul, F., Erdfelder, E., Lang, A.-G., \& Buchner, A. (2007). G*Power 3: A flexible statistical power analysis program for the social, behavioral, and biomedical sciences. Behavior Research Methods, 39, 175-191. https://doi.org/10.3758/BF03193146

Findley, J. D. \& Sales, B. D. (2012). The science of attorney advocacy: How courtroom behavior affects jury decision making. Washington, DC: American Psychological Association.

Flemming, R. B. (1986). Client games: Defense attorney perspectives on their relations with criminal clients. American Bar Foundation Research Journal, 11(2), 253-277.

DOI: $10.1111 / \mathrm{j} .1747-4469.1986 . t b 00241 . x$

Fountain, E. N., \& Woolard, J. L. (2018). How defense attorneys consult with juvenile clients about plea bargains. Psychology Public Policy and Law, 24(2), 192-

\section{3. http://dx.doi.org/10.1037/law0000158}

Greenfield, S. H. (2015, August 25). Jailhouse lawyer, the unicorn in the next cell [Blog post]. Simple Justice: A Criminal Defense Blog. Retrieved from https://blog.simplejustice.us/2015/08/25/jailhouse-lawyers-the-unicorn-in-the-next-cell/

Hahn, P. W. \& Clayton, S. D. (1996). The effects of attorney presentation style, attorney gender, and juror gender on juror decisions. Law and Human Behavior, 20(5), 533-554. https://doi.org/10.1007/BF01499040

Hauser, D. J., Paolacci, G., \& Chandler, J. J. (2018). Common concerns with mturk as a participant pool: Evidence and solutions. In F. Kardes, P. Herr, \& N. Schwarz (Eds.), Handbook in Research Methods in Consumer Psychology. https://doi.org/10.31234/osf.io/uq45c 
Hayes, A. F. (2013). Introduction to Mediation, Moderation, and Conditional Process Analysis. New York, NY: The Guilford Press

Henderson, K. S., \& Levett, L. M. (2018). Investigating predictors of true and false guilty pleas. Law and Human Behavior, 42(5), 427-441. http://dx.doi.org/10.1037/lhb0000297

Hoge, S. K., Bonnie, R. J., Poythress, N., \& Monahan, J. (1992). Attorney-client decisionmaking in criminal cases: Client competence and participation as perceived by their attorneys. Behavioral Sciences \& the Law, 10(3), 385-394. https://doi.org/10.1002/bs1.2370100308

Hovland, C., \& Weiss, W. (1951). The influence of source credibility on communication effectiveness. The Public Opinion Quarterly, 15(4), 635-650. http://www.jstor.org.proxy.lib.pdx.edu/stable/2745952

Kramer, G. M., Wolbransky, M., \& Heilbrun, K. (2007). Plea bargaining recommendations by criminal defense attorneys: Evidence strength, potential sentence, and defendant preference. Behavioral Sciences and the Law, 25, 575-585. doi:10.1002/ bsl.759

Lafler v. Cooper, 132 S. Ct. 1376 (2012)

Larson, B. A. \& Brodsky, S. L. (2010). When cross-examination offends: How men and women assess intrusive questioning of male and female expert witnesses. Journal of Applied Social Psychology, 40(4), 811-830. https://doi.org/10.1111/j.1559-1816.2010.00599.x

Linz, D. G. \& Penrod, S. (1984). Increasing attorney persuasiveness in the courtroom. Law \& Psychology Review, 8(1), 1-47.

McCoy v. Louisiana, S. Ct. 16-8255 (2018) 
McGinnies, E. (1968). Studies in persuasion: IV. source credibility and involvement as factors in persuasion with students in Taiwan. Journal of Social Psychology, 74(2), 171180. https://doi.org/10.1080/00224545.1968.9924843

McGinnies, E. \& Ward, C.D. (1980). Better liked than right: Trustworthiness and expertise as factors in credibility. Personality and Social Psychology Bulletin, 6(3), 467-472. https://doi.org/10.1177\%2F014616728063023

McMann v. Richardson, 397 U.S. 759, 768-74 (1970)

Malloy, L., Shulman, E., Cauffman, E. (2014). Interrogations, confessions, and guilty pleas among serious adolescent offenders. Law and Human Behavior, 38(2), 181-193. http://dx.doi.org/10.1037/lhb0000065

Miranda v. Arizona, 384 U.S. 436, 466 (1966)

Missouri v. Frye, 132 S. Ct. 1399 (2012)

Morgan, K. A. (2018, April). Perceptions of Justice: Views of Jailed Defendants on Procedural and Distributive Justice. Paper presented at a dissertation defense at the University at Albany, SUNY, Albany, NY

Pierce, C. S., \& Brodsky, S. L. (2002). Trust and understanding in the attorney-juvenile relationship. Behavioral Sciences and the Law, 20, 89-107. https://doi.org/10.1002/bsl.478

Parker v. North Carolina, 397 U.S. 790, 794-98 (1970)

Pornpitakpan, C. (2004). The persuasiveness of source credibility: A critical review of five decades' evidence. Journal of Applied Social Psychology, 34(2), 243-281. https://doi.org/10.1111/j.1559-1816.2004.tb02547.x

Powell v. Alabama, 287 U.S. 45 (1932) 
Poythress, N. G., Bonnie, R. J., Hoge, S. K., Monahan, J., \& Oberlander, L. B. (1994). Client abilities to assist counsel and make decisions in criminal cases. Law and Human Behavior, 18(4), 437-452. https://doi.org/10.1007/BF01499049

Redlich, A.D., Bibas, S., Edkins, V.A., \& Madon, S. (2017). The psychology of defendant plea decision making. American Psychologist, 72(4), 339-352. http://dx.doi.org/10.1037/a0040436

Redlich, A.D., \& Shteynberg, R.V. (2016). To plead or not to plead: A comparison of juvenile and adult true and false plea decisions. Law and Human Behavior, 40(6), 611-625. https://psycnet.apa.org/doi/10.1037/lhb0000205

Redlich, A. D., Summers, A., \& Hoover, S. (2010). Self-reported false confessions and false guilty pleas among offenders with mental illness. Law and Human Behavior, 34, 79-90. doi:10.1007/s10979-009-9194-8

Saxe, D. B., \& Kuvin, S. F. (1974). Notes on the attorney-client relationship: A psycholegal overview. The Journal of Psychiatry \& Law, 2(2), 209-216. https://doi.org/10.1177\%2F009318537400200206

Schechtman, E., Shinar, D., Compton, R. C. (1999). The relationship between drinking habits and safe driving behaviors. Transportation Research, 2(1), 15-26. https://doi.org/10.1016/S1369-8478(99)00004-2

Schroeder, P., Meyers, M., \& Kostyniuk, L. (2013). National survey on distracted driving attitudes and behaviors - 2012. (Report No. DOT HS 811 729). Washington, DC: National Highway Traffic Safety Administration. Retrieved from https://www.nhtsa.gov/sites/nhtsa.dot.gov/files/811729.pdf 
Sheehan, K. B. (2018). Crowdsourcing research: Data collection with Amazon's Mechanical Turk. Communication Monographs, 85(1), 140-156. https://doi.org/10.1080/03637751.2017.1342043

Sternthal, B., Dholakia, R., \& Leavitt, C. (1978). The persuasive effect of source credibility: Tests of cognitive response. Journal of Consumer Research, 4(4), 252-260. Retrieved from http://www.jstor.org/stable/2488816

Strickland v. Washington, 466 U.S. 668, 104 S. Ct. 2052, 80 L. Ed. 2d 674 (1984)

Tor, A., Gazal-Ayal, O., Garcia, S. (2010). Fairness and the willingness to accept plea bargain offers. Journal of Empirical Legal Studies, 7(1), 97-116. doi:10.1111/j.17401461.2009.01171.x

https://ucr.fbi.gov/crime-in-the-u.s/2016/crime-in-the-u.s.-2016/topic-pages/tables/table-21

Viljoen, J., Klaver, J., Roesch, R. (2005). Legal decisions of preadolescent and adolescent defendants: Predictors of confessions, pleas, communication with attorneys, and appeals. Law and Human Behavior, 29(3), 253-277. doi: 10.1007/s10979-005-3613-2

Wright, J.S. (1966). The new role of defense counsel under Escobedo and Miranda. American Bar Association Journal, 52(12), 1117-1121. http://www.jstor.org/stable/25723851 
Table 1

Pilot Study Ranking Scores for Attorney Expertise

Item Score Ranking

\begin{tabular}{l}
\hline Attorney seemed familiar with the law in that \\
jurisdiction
\end{tabular}

\begin{tabular}{lll}
\hline Attorney seemed familiar with legal options and & 500 & 2
\end{tabular}

consequences for this type of crime

\begin{tabular}{lll}
\hline Attorney seems informed of facts of the case & 499 & 3
\end{tabular}

$\begin{array}{lll}\text { Attorney seems to have experience with these types of } & 474 & 4\end{array}$

cases (e.g. criminal)

\begin{tabular}{lll}
\hline Attorney seems informed of client's situation & 445 & 5 \\
\hline Attorney informs the client about their legal experience, & 426 & 6 \\
including relevant education and training & & \\
\hline Attorney seemed knowledgeable about best solution to & 407 & 7
\end{tabular}

the case

\begin{tabular}{lll}
\hline Attorney has met with other individuals involved with & 343 & 8
\end{tabular}

the case (e.g. prosecutor, investigator)

\begin{tabular}{lll}
\hline Attorney brings to the client's attention when issues are & 338 & 9
\end{tabular}

beyond his or her legal competence or training

\begin{tabular}{lll}
\hline Attorney seems well prepared for meetings with client & 335 & 10
\end{tabular}

\begin{tabular}{lll}
\hline Attorney appeared confident in meetings with client & 275 & 11
\end{tabular}

\begin{tabular}{lll}
\hline Attorney showed empathy towards client and seemed & 247 & 12
\end{tabular}

interested in their comments 
\begin{tabular}{lll}
\hline Attorney seemed to take control in meetings with client & 156 & 13
\end{tabular}

Note. Factors are ranked from most important factor to least important factor. Scores created by transforming participants' ranked response to a value and summing across individual items (e.g., items ranked $1^{\text {st }}$ out of 13 were given a value of $13,2^{\text {nd }}$ out of 13 were given a value of 12 ). 
Table 2

Pilot Study Ranking Scores for Attorney Trustworthiness

Item Score Ranking

Attorney does what they say they will

562

1

Attorney was honest with client about potential

546

2

consequences

Attorney seems to tell the truth

508

3

\begin{tabular}{lll}
\hline Attorney has regular communication with the client & 398 & $4 / 5^{*}$
\end{tabular}

\begin{tabular}{lll}
\hline Attorney told their client they could depend on them & 398 & $4 / 5^{*}$
\end{tabular}

\begin{tabular}{lll}
\hline Attorney appears to be respected by the judge & 352 & 6
\end{tabular}

Attorney brings to the client's attention when issues are

349

7

beyond his or her legal competence or training

\begin{tabular}{lcc}
\hline Attorney appears to be respected by the prosecutor & 296 & 8 \\
\hline Attorney seems friendly toward their client & 270 & 9 \\
\hline Attorney represented an acquaintance in the past & 240 & 11 \\
\hline Attorney seems to have a friendly relationship with the & 213 & \\
judge & & \\
\end{tabular}

Attorney seems to have a friendly relationship with the $158 \quad 12$ prosecutor

Note. Factors are ranked from most important factor to least important factor. $*$ tied for $4^{\text {th }}$ place in rankings. Scores created by transforming participants' ranked response to a value and summing across individual items (e.g., items ranked $1^{\text {st }}$ out of 13 were given a value of $13,2^{\text {nd }}$ out of 13 were given a value of 12). 
Table 3

Qualitative Motivations for Participants' Decisions: Categories, Percentages, and Descriptions

\begin{tabular}{|c|c|c|c|}
\hline Category & $\begin{array}{l}\text { Agreement } \\
\text { Cronbach's } \alpha\end{array}$ & Percentage & Description \\
\hline Good deal & 0.838 & $24.80 \%$ & $\begin{array}{l}\text { Referenced that plea deal was good and } \\
\text { fair }\end{array}$ \\
\hline $\begin{array}{l}\text { Avoid } \\
\text { punishment }\end{array}$ & 0.930 & $22.80 \%$ & $\begin{array}{l}\text { Desire to avoid punishment such as jail } \\
\text { time, criminal record, collateral } \\
\text { consequences }\end{array}$ \\
\hline Guiltiness & 0.816 & $21.50 \%$ & Referenced guilt \\
\hline $\begin{array}{l}\text { Worse } \\
\text { consequences }\end{array}$ & 0.859 & $16.20 \%$ & $\begin{array}{l}\text { Referenced desire to avoid more severe } \\
\text { consequences (worse sentence, future } \\
\text { bad deals, prosecutor not bargaining in } \\
\text { future) }\end{array}$ \\
\hline Defense-negative & 0.951 & $8.90 \%$ & $\begin{array}{l}\text { Referenced that defense attorney was } \\
\text { unhelpful, unreliable, not putting in } \\
\text { appropriate effort }\end{array}$ \\
\hline Evidence & 0.809 & $8.30 \%$ & $\begin{array}{l}\text { Referenced strength of the evidence } \\
\text { against them }\end{array}$ \\
\hline Accept fault & 0.834 & $7.90 \%$ & $\begin{array}{l}\text { Desire to accept culpability and } \\
\text { responsibility }\end{array}$ \\
\hline
\end{tabular}




\begin{tabular}{|c|c|c|c|}
\hline Defense-positive & 0.977 & $7.60 \%$ & $\begin{array}{l}\text { Referenced that defense attorney was } \\
\text { trustworthy; wanted to follow their } \\
\text { advice }\end{array}$ \\
\hline Plea-instrumental & 0.762 & $7.60 \%$ & $\begin{array}{l}\text { Referenced that the plea is less risky, } \\
\text { more certain, and quicker }\end{array}$ \\
\hline Better offer & 0.893 & $7.00 \%$ & $\begin{array}{l}\text { Expressed desire for future plea offer or } \\
\text { to protest the charges (go to trial) }\end{array}$ \\
\hline Best option & 0.681 & $5.30 \%$ & Referenced that this was the best option \\
\hline Bad deal & 0.819 & $5.00 \%$ & $\begin{array}{l}\text { Referenced that the plea deal was unfair } \\
\text { and bad; found the terms unreasonable }\end{array}$ \\
\hline $\begin{array}{l}\text { Comparable } \\
\text { fairness }\end{array}$ & 0.744 & $4.60 \%$ & $\begin{array}{l}\text { Referenced their perception of how this } \\
\text { type or case should be handled; deal was } \\
\text { fair, better than expected }\end{array}$ \\
\hline No fault & 0.801 & $4.30 \%$ & Denied fault or culpability \\
\hline
\end{tabular}

Note: themes are not mutually exclusive. Percentage indicates percentage of participants who referenced theme as motivation. $N=302$ responses. 
Appendix

\section{Hypothetical Scenario}

\section{$\underline{\text { Charge and case details }}$}

You were driving home after meeting up with friends for drinks to celebrate one of their birthdays last month. You only had two beers, but you hadn't eaten much that day and the effect of the alcohol was noticeable. Still, feeling confident that two beers wouldn't incapacitate you, you said goodnight to your friends and drove home. On the way home, your cell phone slid out of your jacket pocket and under the seat. Instinctively, you glanced down to see where it had fallen and by the time you looked up it was too late; your car jumped the curb and smashed into a lamp post.

Fortunately, you were driving at a relatively low speed and you were able to walk away from the crash without any injuries. As you got out of the car to survey the damage, a police officer showed up. Suspecting alcohol, the officer gave you field sobriety tests, made you recite the alphabet, stand on one leg, and try to touch your nose with one finger. The officer shined a flashlight in your eyes, made you look left and right, and saw that your eyes were red and watery. Even though you passed the sobriety tests, because you had hit a lamp post and your eyes were red and watery, the officer placed you under arrest and then gave you a Breathalyzer test. The test reported that your breath alcohol concentration (BrAC) was .10, just above the legal limit of .08. The officer then took you to the station to get a blood test, which showed that your blood alcohol concentration (BAC) was .09, still just above the .08 limit. You were charged with one count of Driving Under the Influence (DUI).

After the police ran a background check on you, an officer booked you and you spent the remainder of the night in police custody. In the morning, you were taken to criminal court for an arraignment so that the Judge could inform you of the formal criminal charges against you as well as your rights.

Just before the arraignment, you met your defense attorney to discuss the case and your concerns. When you asked your attorney about their experience with these types of cases, your attorney told you that [in their many years practicing, they have handled a lot of drinking and driving cases, and are very familiar with the particular law in this jurisdiction for these types of cases. They told you that you're in good hands / they haven't handled many drinking and driving cases, so this isn't necessarily in their "wheelhouse" of typical cases and that they aren't entirely familiar with the law in this jurisdiction for these types of cases. But they told you that you're in good hands]. Your attorney also told you that the prosecutor does not offer plea deals at arraignment but that they will meet to discuss possible charge or sentence reductions before your next court date.

At the arraignment, the Judge determined that you were not a flight risk and decided not to set bail, so you were released on your own recognizance with instructions to return three weeks later for a possible plea hearing. 


\section{$\underline{\text { Plea Details }}$}

You received the following phone call from your attorney three days before your court date. [As promised in your emails back and forth the last two weeks, your attorney has called you twice already with updates but you are still waiting to hear about the finalized plea offer. Your attorney seems to be as dependable about responding to you as they said they were. I Although you have emailed your attorney several times throughout the last two weeks, they have not replied. And, despite promising to keep you updated with phone calls, this will be your first phone conversation and you are waiting to hear about the finalized plea offer. You're worried that they might not be as dependable as they said they were]. Your attorney said the following:

Good afternoon. I talked with the prosecutor about possible disposition options and now want to relay that information to you. The prosecutor has offered you the following plea deal:

- Regarding the Charge: You would plead guilty to a Conditional Discharge (CD) of 1 year - specifically, this means that if you complete certain conditions (per the sentence penalties specified below) and do not have any new re-arrests or criminal offending within that time period, the conviction will be discharged and when the one year term is over this criminal charge will be sealed by the court and cannot be accessed by most employers.

- Regarding the Sentence: If you plead guilty to the Conditional Discharge, your sentence will include the following penalties:

- Completion of a Drinking and Driving Program.

- Completion of 20 hours of community service. The court will provide you with a list of eligible locations near your home and/or work that you may choose from.

- Driving a car with an Ignition Interlock Device (IID) for 6 months. The device prevents the vehicle from being started until you, the driver, provide an acceptable breath sample under the legal BAC .08 limit.

- A license suspension for 90 days - I negotiated this part of the plea with the prosecutor and was able to get you limited driving privileges that include an exception for driving to or from school or work for yourself and any of your dependents, including children and elderly.

Your attorney then told you [about what they learned from their experience with similar cases and extensive research surrounding possible direct and indirect consequences associated with accepting this specific offer. / they are not entirely sure what the potential consequences would be if you don't accept this specific offer and don't have the time to research them]. Your attorney also told you how they have tried to be very transparent and honest with you about all possibilities. [And you believe them/But you're not so sure that you believe them]. When you asked your attorney about their advice and what they think you should do, your attorney said the following:

[Based on the specific circumstances in this particular case /I'm not entirely sure of the specifics of this case, but regardless] I suggest you accept [reject] this plea offer.

Because really it boils down to this - you never really know if the prosecutor will come back with 
another offer or what that offer will look like. Sure, they could always come back with a better offer. Or they could be annoyed if you reject their offer and decide not to bargain with you anymore, come back with the same offer, or offer a less desirable plea deal than this one. It really could go in any direction. But this is your decision to make. But again, I believe this to be a good offer and think you should accept this offer / I believe this might not be the best offer, and think you should reject this offer].

You will now be asked to make a decision about whether to accept or reject the prosecutor's plea offer. Please make this decision as if this was a true scenario. 